Article

\title{
Envisioning a Catholic Past, Present and Future: Conversion, Recuperation and Andean Christianity in Talavera, Peru
}

\author{
Christine Lee
}

check for updates

Citation: Lee, Christine. 2021.

Envisioning a Catholic Past, Present and Future: Conversion,

Recuperation and Andean

Christianity in Talavera, Peru.

Religions 12: 696. https://doi.org/

$10.3390 /$ rel12090696

Academic Editor: Henri Gooren

Received: 6 August 2021

Accepted: 26 August 2021

Published: 30 August 2021

Publisher's Note: MDPI stays neutral with regard to jurisdictional claims in published maps and institutional affiliations.

Copyright: (C) 2021 by the author. Licensee MDPI, Basel, Switzerland. This article is an open access article distributed under the terms and conditions of the Creative Commons Attribution (CC BY) license (https:/ / creativecommons.org/licenses/by/ $4.0 /)$.
Institute of Anthropology, East China Normal University, Shanghai 200241, China; cl211@st-andrews.ac.uk

\begin{abstract}
In the colonial era, many Spanish missionaries in the Andes sought a total temporal and cultural break between the pagan past and desired a Christian future of indigenous Andeans. Discussions of Christian conversion in the modern-day Andes have often echoed this line of thinking, portraying conversion-whether to Protestantism or to Roman Catholicism-as an event of radical discontinuity, and mapping the rupture of conversion onto the rupture of the Spanish invasion and subsequent evangelisation of the Americas. In doing so, however, scholars have often portrayed Catholicism as a veneer over the 'authentic' Andes-which was assumed to not be Catholic, and indeed could never be. Recently, however, in the south-central Peruvian Andean parish of Talaveraunder the guidance of a first generation of an indigenous Catholic priesthood, made up entirely of men born and raised in the local area-discourses surrounding conversion portray the past as a source of continuity rather than discontinuity with Catholicism. Drawing from historical and ethnographic sources, this article demonstrates that although conversion has been and continues to be an important point of reference in contemporary Roman Catholicism in the Andes, the question of what people convert from has shifted. Today, the Andes are spoken of as already inherently and profoundly Catholic; conversion, in the sense of the need to make the Andes 'really' Catholic, is considered long accomplished. As the article discusses, in a national context where Catholicism is dominant and ubiquitous to the point of hegemony, this is an inherently political stance which runs counter to longstanding harmful stereotypes of indigenous Andeans as not 'real' Catholics and thus unable to be 'real' Peruvians.
\end{abstract}

Keywords: Andes; Catholicism; conversion

\section{Introduction}

From the first few days of fieldwork-when I was still spending most of my time hobbling, slowly, around town trying to acclimate to the altitude-I was struck strongly by Catholicism's ubiquity in Talavera, a small town located almost $3000 \mathrm{~m}$ above sea level in the rural south-central Peruvian Andes. Coming from a non-Christian background myself and accustomed as I was to the casual secularism of the United Kingdom and the United States - where I had grown up and been educated - it initially surprised me that corner shops sold rosaries and crucifixes and keychains with little pictures of saints on them; that as I sat in the plaza catching my breath, I watched person after person casually cross themselves as they passed the church; that every other shop was named after one or another Catholic devotion.

It would have been easy to fit this initial impression into a pervasive scholarly view of Andean Catholicism as merely a veneer under which lay the true, pre-Columbian religion of the Andes. Rooted in the idealistic and highly influential lo andino (meaning 'the Andean') literature of the 1960s and 1970s, scholars in this school envisioned an ahistorical, essentialised core to Andean-ness which had stood defiant against Spanish colonialismespecially, by resisting the imposition of a foreign religion. In this view, despite nearly five centuries of Spanish missionary efforts, the conversion of the Andes had been ultimately shallow and enduringly incomplete. The 'authentic' Andes was not and could never be 
Catholic; to be truly Andean and to be a 'real' Catholic was mutually exclusive. As a result, contemporary indigenous Andean Catholics were seen as caught in an 'eternal' conversion - where conversion had sought but failed to effect the radical break with the past which would have made them properly Catholic (Harris 2006). In this view, although nearly eighty percent of the Talaveran population had identified themselves as Catholic in the 2017 census, this Catholicism was nominal at best and at worst, Talaveran Catholics were tormented by the incompleteness of the initial evangelisation and their own uncertain status in the faith.

Underlying the image of an Andes caught in an eternal conversion is the idea that conversion necessarily demands radical discontinuity, as well as that conversion as radical discontinuity is central to contemporary Christianity (Robbins 2007; Harris 2006; Bialecki et al. 2008). This latter concept stems from a reaction to then-prevailing disciplinary emphases on continuity-which scholars argued was at the cost of engaging with, for instance, rising numbers of converts to Pentecostal and evangelical Christianity who instead foregrounded discontinuity as the key element of their theology and faith. Ironically, however, when applied to Andean Catholicism this formulation echoes those of colonial Spanish missionaries-who often despaired of indigenous Andeans ever becoming 'real' Christians, because they demanded (but rarely were satisfied that they had obtained) that radical break with the past which would mark them as a 'real' Christian convert. This line of thinking has its roots in influential historical discourses: the evangelisation of the Andes was a prolonged and complicated affair, and mainstream Spanish clergy throughout the early and mid-colonial period were generally dissatisfied with the persistence of preConquest Andean traditions. Spanish missionaries, by and large, sought to effect a radical break with the past in their Andean flock-to varying degrees of success. However, such efforts were not universal even during the colonial era; to portray them as such flattens the variety and often outright controversy surrounding efforts to force a radical break on colonial Andean Catholics. The same applies in the modern day: today, Catholicism in the Andes and Talavera in particular is neither a veneer nor defined by conversion. Instead, Catholicism is locally aligned with tradition, and thus seen as a source of continuity rather than discontinuity with the past. I show that Catholicism's place in the Andes, far from being a source of anxiety, is in fact the secure foundation on which clergy in Talavera build their plans for the future of the faith.

The following article discusses two sides to conversion in the Andes, drawing on historical and ethnographic sources. First, I discuss the historical context and foundation for interpretations of Andean conversion as necessarily rooted in interiority and radical discontinuity. Drawing on trial records from the mid-colonial campaign to extirpate idolatry, I show how missionaries' worries about preventing indigenous Andean converts from 'backsliding' were rooted in the gap between Spanish ideals for how conversion should happen and the reality of such. Despite mainstream discourses, conversion was in practice rarely experienced as a singular event; rather, it was more often a gradual and messy process, where the line between 'Andean religion' and 'Catholicism' was not always well-defined or strictly enforced.

The second section draws from sixteen months of participant-observation fieldwork carried out in the south-central Peruvian Andean parish of Talavera, and focuses on modern ethnographic discussions of conversion in the Andes. Contemporary Andean Catholicism undeniably carry the indelible imprint of pre-Hispanic Andean thought, cosmology, and customs. However, this does not necessarily mean that Andean Catholics are not 'real' Catholics: the idea of conversion-especially, conversion as a radical break with the past-as central to Christianity is, as I argue, not universal. While people in Talavera certainly acknowledged that the Andes were now Catholic as the result of past conversion, conversion itself was not an event which was often returned to as a point of reference. Roman Catholicism's secure and powerful place within Peru, and its alignment with Talaveran institutions meant that Catholicism was not generally seen as an unwanted foreign imposition but as something which was domestic, ubiquitous, default. Indeed, 
priests in Talavera spoke of the Andes as already inherently and profoundly Catholiclooking to the past as a source of continuity and a foundation for the future of the faith.

\section{Conversion and the Danger of 'Relapsing'}

In 1723 in Huarochirí-in the northern part of the modern-day Peruvian Andes-a Spanish interrogator for the campaign to extirpate idolatry asked an indigenous Andean man, Juan de Rojas, why he had broken the First Commandment and continued to worship Andean gods despite having been baptised as a Christian. Juan, in return, was "remarkably straightforward" in his reply: that, when he was desperate and had exhausted his other options, he had turned to indigenous religious help, explaining that "many of the confraternity's cattle were dying, and that he had consulted different Indians to help him [so] they might not die" (Mills 1994a, p. 96). Further questioning evidenced that Juan knew his prayers and his doctrine, and that he regularly confessed and received Communion. However, the subsequent discovery of six Christian images along with stone Andean gods among his possessions was interpreted by the prosecutor as a sign of unacceptably mixed loyalties. Because the latter overrode the former, and because this was not his first offence, Juan de Rojas was deemed by the campaign to be a relapso, someone who was "judged to have accepted Christianity at least once, but then to have backslid into religious error" (Mills 1997, p. 96).

As a term, relapso stems from widespread dissatisfaction among Spanish missionariesbeginning in the early colonial period, and coming to a head with the mid-colonial extirpation campaigns-with how the evangelisation of the Andes was proceeding. In particular, Spanish clergy were concerned with whether their conversion to Christianity had been genuine and correct-and their standards for what was a genuine and correct conversion were high and difficult to achieve and ascertain.

In his magnum opus De Procuranda Indorum Salute (On Procuring the Salvation of Indians), the famed Jesuit missionary José de Acosta noted that "the true conversion of Indians to our holy Faith is extremely difficult" (Acosta [1588] 1996a, p. 12), because Christianity called for a "way-of-life completely separated from greed and self-seeking and demands that we cut out, root and branch, all forms of vice that are congenital in our nature and with their use becomes profoundly deeply-seated" (Acosta [1588] 1996a, p. 12). Along with the Spanish insistence that the rejection of Andean culture was absolutely necessary for an authentic and proper conversion, many Spanish missionaries saw 'true conversion' as a project which would take many generations to complete. For instance, the Jesuit father Hernández argued that pre-colonial Andean living patterns "made the natives' ... conversion to Christianity impossible" (Hyland 2003b, p. 49); the Jesuit missionary José de Acosta saw Andean customs as a "highly durable whole that, when passed from mother to son, impeded the path of Christianity" (Hyland 2003b, p. 69).

Compounding these difficulties, by the time of the Spanish invasion of the Americas, wider sixteenth-century European debates over "exterior versus interior forms of worship [meant] many theologians viewed interior sentiment and consent to God as more worth than exterior acts of devotion" (Hyland 2003a, p. 11). As a result, the Spanish desired not just an exterior but also an interior rejection of pre-Hispanic customs and a radical break became ever more difficult to achieve. For Acosta, for instance, it "was not enough that the native people were brought to worship the Christian god with Christian rites in Christian churches; [Acosta] complained that the Indians did not truly adore the lord 'in their hearts' and that their children and grandchildren likewise lacked an interior faith" (Hyland 2003b, p. 67). Although Acosta did lay some blame at the feet of Spanish Christians for their "terrible example and wanton way-of-life" (Acosta [1588] 1996a, p. 94)—one could not realistically expect recent Andean Christians to do better than Spanish Christiansstandards for Andean conversion to Christianity to be considered authentic or genuine were still in practice much higher than they had been for converts in previous centuries.

Yet, this vision of how conversion should be-although common and dominant-was not universal. The Mercedarian order, for instance, held for historical reasons to a "more 
medieval idea of conversion which emphasised the acceptance of baptism rather than the heartfelt conversion and long catechesis demanded by the Jesuits and Dominicans" (Hyland 1998, p. 436), and as a result were generally satisfied by the quality of conversions in their parishes. Blas Valera, a Jesuit contemporary of Acosta, presented Andean religion in his An Account of the Ancient Customs of the Natives of Peru as a "precursor to Christianity, and [which] therefore mirrored Christian beliefs and practices in many ways" (Hyland 2003a, p. 3). He argued that the Incas especially had paved the way for the arrival and spread of Christianity, and so he framed Andean conversion to Christianity not as a radical break but instead one which had continuity with the pre-Columbian past. Likewise, in his desire to affirm Andean conversions in Spanish terms, Valera also maintained that "Andeans confessed to 'evil desires' as well as to exterior acts of sin" (Hyland 2003a, p. 11). In doing so, Andean conversion to Christianity could be portrayed as serious and genuine-that is, as interior.

Nevertheless, the emphasis on and anxiety over whether Andeans had really managed to make a clean break with the past came to a head during the mid-colonial period. By the end of the seventeenth century in Peru, a missionary- and parish-centred style of evangelisation had faded in favour of one focused on rooting out idolatry. As such, "official support grew quickly for a systematic and forceful initiative to solve the widespread problem of religious error and to continue the absorption of Indians into Christendom" (Mills 1994b, p. 88). Its most powerful advocate, Pedro Villagómez, envisioned the Extirpation as the "ultimate antidote to suspect Andean religiosity" (Mills 1994a, p. 285), with the goal of "[separating] and [punishing] the heretics, who could contaminate the Christians" (Duviols 2003, p. 49). In his extirpation manual The Extirpation of Idolatry in Peru, the Jesuit Pablo José Arriaga—a fervent supporter of the campaigns—described idolatry as "so ancient an evil, and one so deeply ingrained and natural to the Indians" (Arriaga [1621] 1968, p. 9) that it was virtually to be expected that Andean converts would 'backslide'. After all, he argued, idolatry still appeared in the Spain after six hundred years of Catholicism, so it was hardly surprising that it persisted in the Andes after only ninety years of Catholicism. As he saw it, one of the main causes of idolatry was that "that up to now their huacas, malquis [ancestor mummies], conopas, and other incitements ... [had] not been taken away" (Arriaga [1621] 1968, p. 90). His proposed solution was that Andeans should have their idols confiscated and destroyed, to be shown the error of their ways and punished for them harshly enough so they would not stray in future. Otherwise, he argued, "the problem of setting aright and causing to be forgotten errors of belief learned at a mother's breast and inherited from father to son" (Arriaga [1621] 1968, p. 9) would never be solved.

By this point, a century after the initial evangelisation, Christianity was not new to the Andes, yet Andeans continued to practice Christianity in ways were not recognisable to mainstream Spanish clergy as Christianity. In 1652, Don Jerónimo Julca was condemned as an "obstinate backslider and idolater" (Mills 1994b, p. 96) for having repeatedly concealed ancestor mummies from the authorities. He was punished with exile to Lima, and his house was burned to the ground. In 1609, Hernando Pauccar, a renowned Andean minister, was sentenced to public shaming and castigation. He suffered two hundred lashes, his hair was shorn, and he was publicly tied to a pole and made to watch while collected idols were burned. He was also exiled to the Jesuit college in Santiago de Chile, where his teachings and presence would not tempt Andean Christians to backslide (Mills 1997, p. 31).

An important factor in determining the severity of idolatry was, as before, the matter of one's interior state while performing idolatrous acts. In 1696, eighty-year-old María Puyron was accused of 'diabolic arts' for assisting Don Juan de Guzmán in his love life with the use of powders to "commend him to the sun" (Mills 1997, p. 119). In response to the judge's questions, María herself replied that it had not seemed so evil to her to bring about a marriage, adding that she had offered the powders "with no more art than believing in her heart that there would be a marriage" (Mills 1997, p. 120). During the trial of Juan Vásques for practicing Andean healing, he said that he had initially ceased because he 
recognised his practices as opposed to Christian customs-but then was reprimanded by a Catholic priest for not sharing such a gift from God (Griffiths 2006). This priest reportedly told him that the only way he could atone was by sharing his gift and resuming practicing Andean healing. Accused nonetheless for his behaviour, Vásques' defender during the trial focused on his interior beliefs and state of mind during the acts in question. The strategy paid off, and Vásques was ultimately acquitted on the grounds that although the acts themselves were heretical, in examinations he had shown himself to be firm in the faith and thus of sound belief whilst carrying out the acts. Thus, he could not actually be a heretic-because although he had done such acts, his interior state was not that of one.

The interpretation of an authentic conversion as founded on, one, a specific interior orientation and two, a radical break with the past, is one with deep roots and relevance in the Andes, stretching back to the initial evangelisation of the Americas. Many Spanish missionaries did view conversion in this sense as crucial to achieving a Catholic Andes, and it was-broadly speaking - the dominant and mainstream narrative. By the time of the campaign to extirpate idolatry, the initial evangelisation of the Andes had been about a century ago-long ago for it to have passed from direct living memory, but recent enough that a generational recollection of what it had been like before lingered still. Mainstream clergy sought to enforce a rejection of the pre-Hispanic Andes, rooted in their conviction that if this break were not accomplished to their satisfaction, the Andes would never be truly Catholic - at least, not by their standards. Nevertheless, the mainstream idea of the Andean and the Catholic as mutually exclusive were not universal: a plethora of prominent voices fought back against it, instead seeking to enact conversion as a gentler, more gradual and accommodating practice. Furthermore, historical records show that conversion was experienced in a much more uneven and gradual fashion than mainstream missionaries idealised. Even as prominent clergy fought over who qualified as a 'real' Catholic, many everyday Andeans practiced their Catholicism in ways that made sense to them as Catholicism and built on pre-Hispanic understandings of the world.

\section{A Catholic Past, Present and Future}

The influence of the mainstream colonial model lingers among anthropologists, albeit refracted through different priorities. In emphasising the persistence of Andean customs in Andean Catholicism (and therefore that Andean Catholicism was not 'really' Catholicism), lo andino scholars sought to communicate a positive portrayal, something which demonstrated the incredible resilience of Andeans in the face of centuries of imperialism. Yet, the reproduction of the disjuncture between the Andean and the Catholic has produced an understanding implicit to many ethnographies of Andean religion-that because the evangelisation of the Andes did not manage to effect the radical break it sought, the conversion of the Andes had been a failure. The scholar Joseph Bastien-a Maryknoll missionary turned anthropologist of the Bolivian Andes-wrote that he had initially been "oblivious to an ancient Andean religion" (Bastien 1978, p. xv) and subsequently realised that the "Catholic religion was as foreign to [the Andes] as I was" (Bastien 1978, p. xv). Discussing the colonial millenarian movement Taki Onqoy, the anthropologist Michael Sallnow described it as a "fundamental contradiction" (Sallnow 1987, p. 269) that Andean Catholic shrines "are Christian, specifically Catholic holy sites ... but at the same time they are Andean" (Sallnow 1987, p. 269), finally concluding that "there can be no ultimate compromise or accommodation here: only a persistent split in religious belief and practice, a manifestation of relentless cultural antagonism that history has visited upon the Andean peoples" (Sallnow 1987, p. 269). The British social anthropologist Olivia Harris argued that because sixteenth-century missionaries "demanded a denial of the past" (Harris 2006, p. 53) and laid down "very exalted conditions ... for what constitutes a good Christian, or even a good enough Christian, [which meant] that this state is almost unattainable" (Harris 2006, p. 53), modern Andean Catholics now experience an "eternal return to the point of conversion" (Harris 2006, p. 71). Ironically, such narratives echo stereotypes within Peru of rural Andean Catholicism as 'syncretic' and, implicitly, inauthentic despite five centuries 
of evangelisation - which then serve to reinforce prejudices regarding rural Andeans as impossible to 'civilise' and bring into the Peruvian nation.

Underlying such accounts is the assumption there must have been a radical break involved for Andean conversion to Christianity to have been genuine. Describing Christianity as a conversion religion which creates an "absolute break between a pre-Christian past and the present" (Harris 2006, p. 53), Harris suggests that a "concern with the incompleteness of conversion is a leitmotif of Christianity in a much more general sense" (Harris 2006, p. 72). This aligns with the idea that rupture is key to Christianity at large: that in the wake of an impossibly demanding conversion, 'eternal' torment is the result of their perpetual inability to live up to the demands of their new religion (Robbins 2004). Lo andino scholars like Harris and Bastien sought to emphasise continuity in the form of an ahistorical essentialised Andean-ness which survived colonialism unscathed-but ironically, in doing so, they were following colonial missionaries' model of Christianity as built on discontinuity.

Today, however, priests in Talavera are-by and large- not concerned about conversion to Catholicism. They themselves are part of the first generation of indigenous Andean clergy in the area, made up entirely of men who were born and raised in local indigenous Catholic communities. All were trained in the local seminary in Abancay-founded in the 1970s by a previous bishop, Msgr. Enrique Pélach, who was highly conservative but locally renowned for his command of the indigenous language, Quechua, and for his sympathy for local Andean customs and people (Lee 2019, 2021). During his tenure as bishop from 1968 to 1992 - the decades directly following the Second Vatican Council and the 'opening up' of the Catholic Church that it sparked-he not only founded the seminary with the aim of fostering a generation of indigenous clergy, but also undertook a number of other initiatives focused on the revitalisation of local Andean Catholicism such as the revival of regional pilgrimages and other festivals (Lee 2021). The local curate observed to me that Catholicism's time for conversion had long passed; now, he said, people are born to Catholicism-implicitly also indicating, in the spirit of Msgr Enrique's endeavours, that the Andean past and Andean culture were no longer to be regarded as a threat to Christianity. Nor are they hyperfocused on interiority as a defining feature of Catholic identity. Although priests are concerned with the quality of local Catholicism - whether people know their catechism, are behaving in accordance with Catholic moral and social teaching, are taking Communion and confessing regularly - they do not wonder whether they are 'really' Catholics. It is taken for granted that Talaverans are Catholic. Among the lay Catholics who I met through the parish offices, the majority did not regard their Catholic identity as a matter which required active upkeep: for them, they simply were Catholics-they had been born as such, raised as such, and they generally intended to continue living as such. Yet, they never doubted that they themselves were Catholic - and indeed, by and large regarded Catholicism as the default state of affairs. This sense of security is bolstered by Catholicism's strong influence in Peruvian—and Talaveran—institutions, permeating public and private life.

Catholicism is a key element of Peruvian identity. At the national level, it is enshrined in Article 50 of the Constitution, where the state explicitly "recognises the Catholic Church as an important element in the historical, cultural, and moral formation of Peru, and lends the church its cooperation". Each Independence Day is celebrated with a Te Deum Mass, said by the cardinal in the cathedral in Lima and attended by the president, which is then broadcast nationally. The link between being Peruvian and being Catholic is reinforced by, for instance, mandatory religion education classes in public primary and secondary schools-often taught by priests and nuns who want to earn a little extra money on the side. Such classes teach specifically Catholic doctrine, morals, and theology. For example, in 2016, one of the priests in Talavera set these three questions on an exam for fifteen year old students:

(1) According to 1 Corinthians 12,12-28, what would be the best definition of the Church?

(2) What are the Marks of the Church? 
(3) If in Exodus 20, 4-6, God prohibits idolatry and in Exodus 25, 10-22 the same God instructs that the Ark of the Covenant be made, what is your assessment of the Word of God in these two Biblical quotations?

Correct answers followed specifically Catholic lines. This is especially notable in the third question, which expected students to say that the Ark of the Covenant was not idolatry, and that veneration is not the same as idolatry. It may seem at first glance that this question was designed to defend Andean religiosity - but in fact, in this context, it is a question pointed squarely at local evangelical Protestants who commonly accused Catholics of idolatry for worshipping images and saints. From the perspective of the priests - and many other Catholics in Talavera-if there is a threat to Catholicism, it comes not from Andean folk religion but from growing numbers of evangelical Protestants.

Evangelicals were a significant presence in Talavera-according to the 2017 census, about $20 \%$ of Talaverans identified as such. This constitutes a dramatic and swift increase in Protestantism locally, and virtually all evangelicals were converts to Protestantism from Catholicism. Although Protestants have been present in Peru for upwards of a century, they were few in number and generally isolated until recently, especially in the rural Andes. The parish priest in Talavera - who was himself from a rural Andean village in a neighbouring province-recalled clearly the first two people to convert to Protestantism in his natal community, sometime in the 1980s. Similarly, thirty or forty years ago there would have been virtually no one in Talavera who would have called themselves a Protestant, a trend which matches the area at large. Fumerton $(2002$, p. 246) noted that between 1981 and 1993, the number of Protestants in the nearby region of Ayacucho nearly tripled (from about $4 \%$ to almost $12 \%$ ), while in Bolivia, the number of Protestants more than doubled between 1992 and 2001 from about 10\% to 25\% (Canessa 2000; Lazar 2008). As a result, much of the modern ethnographic literature on Christianity in the Andes has been devoted to analysing why Protestantism has suddenly exploded in popularity in the region, especially among indigenous people - is it due to its ability to provide a "new sense of religiosity and community"? (Canessa 1998, p. 121). Or perhaps it is due to the stress of migration (Gill 1990), and the appeal of the strict morals involved which reduce domestic violence, philandering and money spent on alcohol (Brusco 1993; Gill 1990, 1993; Green 1993).

At the same time, despite this notably rapid rise, evangelicals constitute a distinct minority - albeit a visible and often vocal one-in communities such as Talavera. Local priests devoted some time to countering popular accusations levied by evangelical Protestants against Catholicism, such as that of idolatry. Many also regularly posted on social media about, for instance, why the Protestant Bible was incorrect or why Martin Luther had been wrong about certain doctrinal matters. Nonetheless, the priests I spoke to did not feel significantly threatened-yet, anyway - by evangelical Protestants. They were still primarily only a minor worry, relatively removed from the everyday business of running a parish. Plus, the priests felt themselves and the Church to be in the majority, and to be supported by the institutions that surrounded them which were all still imbued with Catholicism. This sense of institutional and structural Catholicism was pervasive and powerful even outside of the clergy, and penetrated into even the lives of non-Catholics.

During fieldwork, I gathered data primarily via volunteering as parish secretary, which put me in close contact not only with the parish priest and his curate, but also with local parishioners and residents. One of my main duties as secretary was to issue baptism, confirmation and marriage certificates, commonly requested documents for a variety of religious and civil needs. Most of the people who came into the office were Catholics, but this was not always the case. One afternoon, a man named Silvio came in with his wife, asking to look up his mother's baptism certificate. Her name had been María Gonzales Allccahuaman, he said, and she had been born in Talavera in 1937.

Silvio had a long untrimmed beard and his wife wore a brightly coloured headscarfmarking them as members of the Israelitas, a Christian denomination which had been founded in the mid-twentieth century by a man in central Peru who claimed he was God's third chosen prophet after Moses and Jesus. They refused to address the priest as Father, 
and instead called him Mister or Sir. Nevertheless, they had come into a Catholic parish office because after María's passing a few years ago, it had come to light that her national identification document (DNI) and her birth certificate did not match: while her DNI and other documents recorded her surname as Gonzales, her birth certificate had registered it as Gonzalez. Silvio's documents all listed his maternal surname as Gonzales-and because this did not match his mother's birth certificate, he had been unable to be legally recognised as María's son and had thus been prevented from receiving his inheritance. In order to do so, he would first need to get his mother's surname on her birth certificate formally corrected, from Gonzalez to Gonzales.

If María had still been alive, there would have been various avenues for doing this. Now that she had passed away, however, Silvio had been told he had only two options for rectification. Since church documents-especially baptism and marriage certificateswere able to serve as legal proof of identity for civil purposes in Talavera, if her baptism certificate had the correct spelling on it, they would be able to use this to correct her legal birth certificate. The town hall clerk had recommended this to Silvio as the easiest and most straightforward option. If they were unlucky, however, and her baptism certificate had been misspelled as well-then the only other option for a rectification would be through a lengthy and expensive legal process. Silvio would have to hire a lawyer; a case would have to be presented to a judge; reams of documentation would have to be put together. Fortunately, when I looked up María's baptism records, the priest had recorded her surname correctly as Gonzales. Upon hearing this news, Silvio gave a great sigh of relief, paid the fee for a certificate, and left with his wife presumably for the town hall.

The reach of the state was relatively slow to arrive in the area surrounding Talavera, considered one of the more remote and rural regions of Peru. In its absence, the Church retained a significant amount of structural and institutional power for longer than it did in other parts of the country. For instance, there are no reliable civil records in Talavera before 1936 - the only records of birth and marriage belong to the Catholic Church. Local secular civil and legal documentation processes continue to include and depend on the Church-meaning that even staunch non-Catholic such as Silvio were required to interact with Catholicism in some capacity, for matters as personal as his inheritance.

The intertwining of the Catholic Church and public institutions also manifested through the duties of priests in their capacity as public figures. Official requests often arrived from the town hall asking that for the priest's presence at one service or another. One week, it was a ceremony in honour of a particular department's recent acquisition of some new cars. The man who delivered the paperwork for the request asked me to please bring the matter to the priest's attention, and to tell him that they would like him to say a few words and bless the cars. When I mentioned this to the priest later that day, he groaned a little and looked over the paperwork. "I'll go at . . 10:30," he said. In response to my look-because the schedule said that the ceremony started at 9:30—he said, "oh, it'll be fine, they never start on time," in tones which implied that he had been to many of these affairs before, arrived more or less on time, and had then had to stand around waiting for an hour. (As it happened, he went a little earlier than he had intended, at 10:00 — and then wound up waiting half an hour for them to start.)

As his casual attitude suggested, such occasions were routine for him. Every year, for instance, the police processed an image of Saint Rose of Lima, the patron saint of the national Peruvian police through the streets of Talavera, and he was asked every year to celebrate a Mass for them in her honour. The local hospital had a patron, too-the Infant Jesus of Prague; they had a little statue of him in their chapel-and the medical staff requested every year that he bless the statue and celebrate Mass in their chapel on the Child's feast day. Likewise, public schools in and around Talavera would also ask the priest to celebrate Masses for their patrons-such as the primary school two doors down from the parish offices, which was named after the Sacred Heart of Jesus and always asked every year for a special Mass for the occasion. These Masses were major and prestigious events for the institution. The representative from the Sacred Heart of Jesus primary school was 
keen to emphasise that they did not want a simple Mass but with as much ceremony and ritual as could be mustered, listing incense; altar boys; offerings; a procession if possible.

Although for some of the more minor occasions, it may have been possible to simply not attend if one was not Catholic, in a number of cases I knew evangelicals who had been obliged to participate and even lead in Mass as part of their work duties-sometimes running against the grain of the institutional hierarchy. When the teachers came from the Sacred Heart of Jesus school to schedule their Mass, one of them told me rather triumphantly that it was actually the lower-ranking teachers who had been arranging everything; the school principal was Protestant and had thus conveniently forgotten about it. Another time, at one point the religious education teacher at a school just outside Talavera had asked the priest to celebrate Mass for all the students and staff. Afterwards, the priest recounted to me-chortling-how the school principal (known to be an evangelical Protestant) had been seated in pride of place in the front row and as such had been obliged to lead the entire school in clapping and stomping along to the music. Evidently, a few of the teachers were not showing much enthusiasm - until the principal yelled back that any teachers who would not clap along would have to come up to the front row with her.

Catholicism's influence in Peru is immense, and as shown, it permeates public life to the point where it can penetrate private matters as well. Peru has been officially Catholic for almost five hundred years; for comparison, that is approximately the same amount of time that England, for instance, has been officially Anglican. Its central and longstanding role in Peruvian history is the foundation for why the parish priest once indignantly said-as he watched a debate on the news about the Catholic Church's stance on contraceptionthat rather than criticising, the nation should in fact offer thanks to the Church for the hundreds of years of moral formation the Church had offered. Far from being a source of discontinuity with the past, priests drew on Catholicism as a source of continuity with the past-including in the Andes. Indeed, in conversation, the parish priest generally spoke of the Andean past as a time when people had been more devout and better Catholics than they were now.

When assessing the needs and future development of the parish, the priests did worry about the quality of local Catholicism. A common concern was that parishioners did not know their catechism, their prayers or their doctrine, a worry which was often refracted through moral concerns. For example, lay Catholics who engaged in premarital sex, or got divorced, or tried to use contraception. The parish priest also worried about domestic violence and general hardheartedness, as well as selfishness and lack of charity among people-elements which for him stemmed from a lack of real, profound understanding of Christianity and what it taught about how people should treat one another.

Notably, however, I never heard any of the priests focus on indigenous Catholicism, or Andean culture, as a problem. In matters of morality especially, urban-i.e., less Andeanparishioners were seen as the main part of the problem, while if anything rural indigenous parishioners were valorised and praised. The parish priest in Talavera was himself from a rural Andean community, and had been raised as a Catholic — and told me that he had had no sense of the Andean Catholicism he had grown up with as somehow inferior or disingenuous for its Andean elements. Certainly, distinctively Andean religious practices continued alongside Catholic ones, such as the making of offerings to certain mountainsa ritual he witnessed himself as a child. However, he told me, he never received the impression that such ceremonies were born of a real belief in mountain spirits, but rather of respect to one's elders. He also acknowledged that rural parishioners sometimes had a patchy knowledge of the catechism, due to a lack of education and a shortage of capable catechists, but none of this, for him, implied that rural Andean Catholics were somehow less or not Catholic. To the contrary-he repeatedly emphasised to me that if anything, the people living in the rural countryside had more faith than those living in town. Even among the lay Catholics I spoke to, I rarely encountered the idea that Andean customs necessarily meant that indigenous Andean were not 'really' Catholic. When such ideas did circulate, they tended to focus not on local indigenous customs but on indigenous 
customs of other parts of the Andes such as Puno, which is highly stigmatised even within the Andes for its altitude (nearly $4000 \mathrm{~m}$ above sea level) and location at the southern edge of Peru on the altiplano bordering Bolivia (Lee 2019).

In a conversation with the priest some months after I had left Talavera, he sent me photos of a Mass he had recently celebrated in one of the rural communities-marked by traditional folk dances in honour of the Virgin whose feast it was-and added that they were "working to recuperate the faith". This instance was part of his wider vision for the parish: the revitalisation of (rather than conversion to) the Catholic faith. His plans for how to address this included the further development of parish groups, such as the local chapter of the Catholic Charismatic Renewal; cultivation and training of catechists who could teach in rural communities; and engagement with existing local traditions, such as by including folk dances in celebrations. This particular priest had already undertaken such a project in a previous parish he had been assigned to, where parishioners had told me that due to his efforts the church had become active and lively again. Reportedly, the revival of the parish had drawn in so many previously disengaged Catholics that an evangelical pastor barged into the church during Holy Week and tried to bodily drag some of his former congregants back to his church.

Far from imagining a non-Christian, pagan Andes, these priests envisioned a thoroughly Catholic Andes-one which had, in the past, been even more Catholic than the present. The assuredness and security with which they held this view was possible in significant part due to Catholicism's long and fundamental role in Peruvian history, the power and influence of which was felt in Talavera regardless of one's own religious affiliation. Catholicism was seen as the default; the religion which one was born into, not that one converted to; the faith which was seen as most closely aligned with being Peruvian. Although the priests worried about the quality of local Catholicism, the authenticity of such was never in question. Instead, when seeking to improve local faith, priests explicitly framed it as a matter of recovery and recuperation-of helping parishioners rediscover their faith.

\section{Conclusions}

To frame Andean Catholicism as already genuine in and of itself is an interpretation with distinct political dimensions, as is the case with anthropological interpretations of Andean spirituality more generally (Arkush 2012). Lo andino scholars sought, politically, to depict an Andean people who had resisted colonial oppression against all odds and for centuries. It was towards this end that they described the presence of a core Andeanness which had been able to continue essentially unbroken and unchanged for half a millennium - one that had been so strong that it invalidated centuries of evangelisation efforts. Yet, the implication that indigenous Andeans are not 'really' Catholics has its own negative political connotations, particularly at the national Peruvian level. Many rural Andeans are insecure about the validity of their own Catholicism-despite identifying staunchly as Catholics - because they have "internalised the view that outsiders have of them" (Harris 2006, p. 67). Given that Catholicism is enshrined in the national constitution, and given its immense structural influence in Peru, to cast indigenous Andean Catholics as not 'really' Catholics implicitly also casts them as inferior Peruvians. This is on top of existing racism against indigenous Andeans; the wider area to which Talavera belongs is part of the region referred to by creole elite as the "Indian stain" (Winn 2006) for its poverty and large population of indigenous Andeans.

Like mainstream colonial priests, modern-day priests in Talavera thought that the quality of local Catholicism could be improved. However, mainstream colonial priests framed this in terms of conversion and doubt over the legitimacy of Andean Catholicism, while modern day priests in Talavera framed their goals for improvement in terms of recuperating a Christianity which used to be better but has been lost. Andean religiosity was not seen as a threat; it had already accompanied Catholicism for over half a millennium. 
Whether Andean Catholics were 'authentic' Catholics was not something which they questioned, or saw as a matter of debate.

A model of Christianity which emphasises above all else conversion-and, especially, conversion as a radical break with the past and as interior-effectively erases and invalidates Andean Catholicism as it exists. This not only flattens out the plethora of ways in which Catholicism has integrated with local cultures as it spread around the world (whether organically or by force), but also inadvertently supports anti-indigenous racial prejudices within Peru. To be Catholic in Talavera did not necessarily rest exclusively, or even primarily, on cleaving to a certain orthodoxy or set of doctrines. It was seen as natural to be Catholic; most people were. Catholics were born and raised as such. The greater history of the Catholic Church in Peru, and its accompanying institutional power and cultural cachet, were an inescapable part of local lived experience. It would have been quite possible to live in Talavera without regularly attending Mass-in fact, most people probably did not regularly attend Mass - but it would have been difficult to live in Talavera without interacting in some way with the Catholic Church.

Funding: This research was funded by Santander and the University of St Andrews.

Institutional Review Board Statement: The study was conducted according to the guidelines of the Declaration of Helsinki, and approved by the University of St Andrews Teaching and Research Ethics Committee (reference number SA11439, approved on 31 March 2015).

Informed Consent Statement: Informed consent was obtained from all subjects involved in the study.

Conflicts of Interest: The author declares no conflict of interest. The funders had no role in the design of the study; in the collection, analyses, or interpretation of data; in the writing of the manuscript, or in the decision to publish the results.

\section{References}

Acosta, José de. 1996a. De Procuranda Indorum Salute. Translated and Edited by George Stewart McIntosh. Tayport: Mac Research, vol. 2. First published 1588.

Arkush, Elizabeth. 2012. Violence, indigeneity, and archaeological interpretation in the central Andes. In The Ethics of Anthropology and Amerindian Research: Reporting on Environmental Degradation and Warfare. Edited by Richard Chacon and Rubén Mendoza. New York: Springer.

Arriaga, Pablo José. 1968. The Extirpation of Idolatry in Peru. Translated and Edited by Louis Clark Keating. Lexington: University of Kentucky Press. First published 1621.

Bastien, Joseph. 1978. Mountain of the Condor: Metaphor and Ritual in an Andean Ayllu. St. Paul: West Publishing Co.

Bialecki, Jon, Naomi Haynes, and Joel Robbins. 2008. The anthropology of Christianity. Religion Compass 2: 1139-58. [CrossRef]

Brusco, Elizabeth. 1993. The reformation of machismo: Asceticism and masculinity among Colombian evangelicals. In Rethinking Protestantism in Latin America. Edited by Virginia Garrard-Burnett and David Stoll. Philadelphia: Temple University Press.

Canessa, Andrew. 1998. Procreation, personhood and ethnic difference in highland Bolivia. Ethnos 63: 37-41. [CrossRef]

Canessa, Andrew. 2000. Contesting hybridity: Evangelistas and kataristas in highland Bolivia. Journal of Latin American Studies 32: 115-44. [CrossRef]

Duviols, Pierre. 2003. Procesos y Visitas de Idolatrías: Cajabambo, Siglo XVII. Lima: Instituto Francés de Estudios Andinas; Pontificia Universidad Católica del Perú.

Fumerton, Mario. 2002. From Victims to Heroes: Peasant Counter-Rebellion and Civil War in Ayacucho, Peru, 1980-2000. Amsterdam: Rozenberg Publishers.

Gill, Lesley. 1990. Like a veil to cover them: Women and the Pentecostal movement in La Paz. American Ethnologist 17: 708-21. [CrossRef]

Gill, Lesley. 1993. Religious mobility and the many words of God in La Paz, Bolivia. In Rethinking Protestantism in Latin America. Edited by Virginia Garrard-Burnett and David Stoll. Philadelphia: Temple University Press.

Green, Linda. 1993. Shifting affiliations: Mayan widows and the evangélicos in Guatemala. In Rethinking Protestantism in Latin America. Edited by Virginia Garrard-Burnett and David Stoll. Philadelphia: Temple University Press.

Griffiths, Nicholas. 2006. Sacred Dialogues: Christianity and Native Religion in the Colonial Americas 1492-1700. London: Lulu Enterprises.

Harris, Olivia. 2006. The eternal return of conversion: Christianity as contested domain in highland Bolivia. In The Anthropology of Christianity. Edited by Fenella Cannell. Durham: Duke University Press.

Hyland, Sabine. 1998. Illegitimacy and racial hierarchy in the Peruvian priesthood: A seventeenth-century dispute. The Catholic Historical Review 84: 431-54. [CrossRef] 
Hyland, Sabine. 2003a. Gods of the Andes: An Early Jesuit Account of Inca Religion and Andean Christianity. State College: Pennsylvania State University Press.

Hyland, Sabine. 2003b. The Jesuit and the Incas: The Extraordinary Life of Padre Blas Valera, S.J. Ann Arbor: University of Michigan Press. Lazar, Sian. 2008. El Alto, Rebel City: Self and Citizenship in Andean Bolivia. Durham: Duke University Press.

Lee, Christine. 2019. The Ironic Legacy of an Opus Dei Bishop: Native Priests and Andean Catholicism in Post-Conflict Apurimac. Latin American Perspectives 46: 59-72. [CrossRef]

Lee, Christine. 2021. Towards the Founding of a Native Clergy and the Revival of 'Mamacha Cocharcas': Popular Lived Catholicism in the Wake of Vatican II. Religions 12: 142. [CrossRef]

Mills, Kenneth. 1994a. An Evil Lost to View? An Investigation of Post-Evangelisation Andean Religion in Mid-Colonial Peru. Liverpool: Institute of Latin American Studies, The University of Liverpool.

Mills, Kenneth. 1994b. The limits of religious coercion in mid-colonial Peru. Past E Present 134: 84-121.

Mills, Kenneth. 1997. Idolatry and Its Enemies: Colonial Andean Religion and Extirpation, 1640-1750. Princeton: Princeton University Press.

Robbins, Joel. 2004. Becoming Sinners: Christianity and Moral Torment in a Papua New Guinea Society. Berkeley: University of California Press.

Robbins, Joel. 2007. Continuity thinking and the problem of Christian culture: Belief, time, and the anthropology of Christianity. Current Anthropology 48: 5-38. [CrossRef]

Sallnow, Michael. 1987. Pilgrims of the Andes: Regional Cults in Cusco. Washington: Smithsonian Institution Press.

Winn, Peter. 2006. Americas: The Changing Face of Latin America and the Caribbean. Berkeley: University of California Press. 